\title{
AS FIGURAS PROTETORAS E SEU EFEITO POLÍTICO. REIS E DAIMONES: AS MARCAS DA CUSTÓDIA
}

Maria Cecília Colombani ${ }^{1}$

\begin{abstract}
Resumo
O objetivo deste artigo é analisar as figuras protetoras presentes na Teogonia e em Os trabalhos e os dias. Delas, escolhemos a figura do rei, como garante da ordem e da justiça emanada de Zeus, e os daimones, que são vigilantes invisíveis dos homens. Para isso, utilizaremos os conceitos do Mesmo e do Outro, encarnados em linhagens diurnas e noturnas, a fim de ressaltar as características associadas a essas figuras - traduzidas, em nível textual, em adjetivos e verbos específicos. Da mesma forma, veremos como elas influenciam no equilíbrio político da cidade.
\end{abstract}

\section{Palavras-chave}

Proteção; Vigilância; Rei; Daimon; Hesíodo; Política.

\section{Resumen}

El objetivo de este artículo es analizar las figuras protectoras que se encuentran presentes en Teogonía y Trabajos y dias. De ellas hemos escogido al rey, como garante del orden y la justicia emanada de Zeus, y a los daimones, vigilantes invisibles de los hombres. Para ello utilizaremos los conceptos de lo Mismo y lo Otro, encarnados en linajes diurnos y nocturnos, a fin de subrayar las características asociadas a estas figuras que se traducen a nivel textual en adjetivos y verbos específicos. Asimismo, veremos cómo afectan el equilibrio político de la ciudad.

\section{Palabras clave}

Protección; vigilancia; rey; daimon; Hesíodo; política.

\footnotetext{
${ }^{1}$ Professora Doutora - Universidad de Morón, Morón, Argentina.

E-mail: ceciliacolombani@hotmail.com
} 


\section{Introdução}

"Assim sendo, talvez precisemos escolher entre dois caminhos: ou pensar a mitologia aos golpes do martelo, ou trabalhar como teórico do 'espírito humano'".

Detienne, 1985: 6

O projeto deste trabalho consiste em pensar a perspectiva mítica em Hesíodo como produto do espírito humano - um fruto privilegiado, cuja capacidade nos transporta a uma etho-mitho-poiética: uma produção de sentido que impacta em uma maneira de ser específica.

"Por que falar da mitologia é sempre, mais ou menos explicitamente, falar grego a partir da Grécia?" (Detienne, 1985: 7), pergunta-se M. Detienne, enquanto nos aponta a senda hesiódica com um gesto de coincidência e convergência. Esse atalho significa colocar-se face-a-face com o autor, reconhecendo sua preocupação antropológica e enfatizando, ademais, uma atitude problematizante que o distingue de Homero e o situa em um plano que beira a inquietação filosófica.

Às já conhecidas teses nas quais Hesíodo aparece como um primeiro filósofo ou, pelo menos, como o claro expoente de um pensamento pré-conceitual, ${ }^{2}$ queremos contribuir com uma perspectiva na qual sua inserção no topos da especulação primária, ou, melhor, da incipiente atitude filosófica, está ligada ao seu nível de problematização da realidade na qual se insere, buscando dar conta de uma "preocupação história" como resposta a uma configuração específica de sua época.

Por esse hiato, explica-se a escolha dos diferentes tópicos deste trabalho. Em primeiro lugar, a figura do rei justo como contrapartida dos reis devoradores de presentes, os dorophagoi; e, em segundo, os daimones, que surgem logo após o desaparecimento dos homens da raça de ouro no Mito das Idades. Figuras protetoras inscritas em uma linhagem luminosa, cuja missão consiste em preservar a ordem e cuidar dos homens.

\footnotetext{
${ }^{2}$ Nesse sentido, distingue-se claramente Olof Gigon e inscreve-se também minha tese doutoral, "Una aproximación arqueológica al discurso hesiódico desde la lógica del linaje" (2016), onde busquei mostrar a pertinência e o pertencimento filosófico de Hesíodo a partir da consideração do esquema conceitual que dá sustentação à sua obra, pensada a partir de sua consolidação arquitetônica, com base na existência de duas linhagens como operadores discursivos e conceituais.
} 


\title{
A lógica da linhagem. A arquitetura do real
}

\begin{abstract}
“De onde provém o saber tão plástico que permite a uma mesma palavra - mitologia - designar as práticas narrativas, os relatos conhecidos por todos e os discursos interpretativos que, desde meados do século XIX, mencionam-na pela modalidade e com o tom de uma ciência?"
\end{abstract}

Detienne, 1985: 7

A novidade hesiódica, a nosso entender, está no marco que serve de arquitetura e andaime à sua obra, inscrito no que chamaremos de a lógica da linhagem. Consideramos que a ideia representada por Hesíodo no final do século VIII e início do VII a.C. tem por base a maneira de apresentar os seus poemas, sendo que ambos se sustentam nessa lógica como arquitetura discursiva e conceitual.

Dentro desse marco, devemos definir a linhagem como um operador discursivo que permite ordenar o complexo campo, sempre tenso e polêmico, do Mesmo e do Outro. Tal resistência é um pilar do presente trabalho e da produção hesiódica em geral, uma vez que, segundo nosso modelo de instalação, pode-se concluir que ambos os poemas em tela contêm uma espécie de preocupação antropológica, pela qual esse tenso território se resolve em termos de linhagem - um positivo, de matriz diurna e luminosa, e outro negativo, de matriz noturna e tenebrosa.

Pensemos alguns tópicos que permitem uma aproximação significativa com os poemas a partir da noção de linhagem. ${ }^{3}$ Como um operador discursivo, a linhagem nos conduz ao nível da significação e situa o mito como um logos explicativo que, a partir do assombro, busca expor o real sob sua lógica imperante. A linhagem como operador discursivo é a noção que possibilita a operação classificatória dos campos aludidos, territorializando o Mesmo e o Outro em tópoi opostos e complementares. Isso está pensado a partir do plasmar de duas séries, uma positiva e outra negativa, uma diurna e outra noturna, que atuam como eixos discursivos e conceituais, e que abarcam, em sua geografia, a representação simbólica de todas as coisas. Com isso, permite uma classificação de tipo cosmológica e ético-antropológica, e possibilita a ordenação de diferentes tipos de realidades: a divina, a cósmica e a humana. Hesíodo se situa no plano de um "primeiro balbuciar filosófico" ou, pelo menos, acerca-se poeticamente de questões que mais adiante serão

\footnotetext{
${ }^{3}$ Esta seção revisita minha tese de doutoramento (ver Nota de rodapé 1 acima), que foi publicada com o título "Hesíodo. Discurso y Linaje. Una aproximación arqueológica" (2016). Introdução.
} 
a própria tarefa do filosofar. Ao fazê-lo, gera um complexo trânsito entre mito e filosofia.

A lógica da linhagem pressupõe compreendê-la como ferramenta conceitual e interpretativa para abordar o nosso topos instaurador, isto é, o mito como campo de significação axiomática. Por isso, nosso ponto de ancoragem nos abaliza a existência de dois campos simbólicos que permitem classificar, ordenar e ressignificar a complexidade do real. Devemos também aceitar que na lógica da linhagem existe uma descendência diversa, heterogênea, capaz de mesclar luminosidade e tenebrosidade, claridade e escuridão, matizando as dicotomias do esquema, próprio de sua inscrição em uma lógica da ambiguidade (Detienne, 1986: 15-20).

O diagrama de forças que essas linhagens representam, em clara perspectiva agonística, é a chave que possibilita a pretensão de Hesíodo - "ambições, por assim dizer, unitárias; essas grandes e complexas descrições que, ademais, pelo menos no caso dos dois primeiros poemas, representam uma visão idealizada: o progresso do mundo consiste na implantação da ordem de Zeus, que garante a justiça" (Rodríguez Adrados, 2001: 199).

Nesse contexto, que também caracteriza um projeto didático-moralizador, a lógica da linhagem se perfaz como operadora de sentido e condição de possibilidade de uma arquitetura que situa as potências negativas e positivas em planos diferenciados - em territórios opostos, porém complementares -, o que imprime uma ordem lógica à obra e provê um fio condutor entre ambos os poemas, uma vez que, mais além de suas diferenças, eles convergem rumo a uma unidade didática que prioriza a justiça imposta e garantida por Zeus.

Em ambos os poemas, ficam assim instituídos dois territórios conceituais, definidos em termos de linhagem, que permitem classificar essa totalidade do Ser que incorpora tanto o mundo natural como o humano em um sistema de significação compacto, e abarca a complexidade estrutural do mito. Isso não implica, como já antecipamos, que não surjam ambiguidades e mesclas, bifurcações e atalhos que aumentem a complexidade do diagrama de forças dessas duas linhagens, ao mesmo tempo em que o enriquecem simbolicamente. A partir disso, propomo-nos a destacar a figura dos reis descendentes de Zeus e dos daimones, priorizando uma interpretação ligada ao cuidado ou atenção com os mortais e sua proteção. 


\section{O rei. Teogonia, um sentido possível}

“O que é que faz com que o assim-chamado mito seja habitado ou tomado por uma necessidade de falar, por um desejo de saber, por uma vontade de buscar o sentido - a razão do discurso considerado em si mesmo?"

Detienne, 1985: 11

A citação acima, que abre a presente seção deste texto, aponta-nos a direção a seguir, uma vez que é disso que se trata: de buscar um sentido possível dentro dessa lógica que nos pusemos a desenvolver. A figura do rei, positiva e diurna, reflete uma série de características que nos permitem considerar algumas dimensões e funções da soberania. Entre elas, concentremo-nos na proteção e no cuidado, ou atenção, como tópoi de análise.

Com efeito, propomo-nos a pensar a perspectiva da proteção da justiça e da verdade como forma de garantir a função da soberania e a coesão de uma aldeia, preservando-a da nefasta influência dos reis devoradores de presentes, inscritos em uma linhagem tenebrosa com base nos seus traços identitários. Tais reis representam uma contrafigura e um elemento disruptivo no contexto do que nos propusemos a pensar como uma "metáfora médica": figuras do Outro que, com seu modo de ministrar a justiça, determinam um manifesto dano à cidade a partir do desconhecimento das retas sentenças.

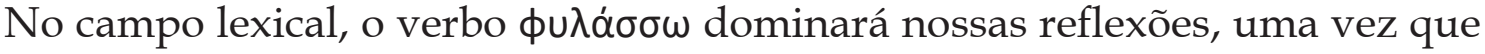
nos orientamos a considerar uma função de proteção, de cuidado, de vigilância da observância das leis, que, por advirem de Zeus, são as melhores. Para compreender o papel dos reis descendentes de Zeus, é necessário apontar a sua solidariedade com as Musas ${ }^{4}$. As Musas são os verdadeiros artífices da inscrição luminosa do rei. São elas que o veem nascer e lhe outorgam o privilégio real ${ }^{5}$.

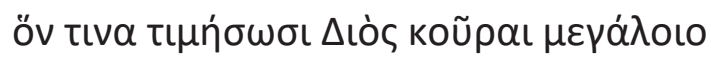

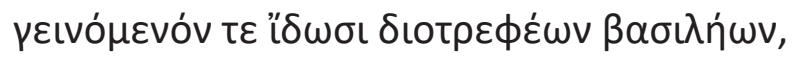

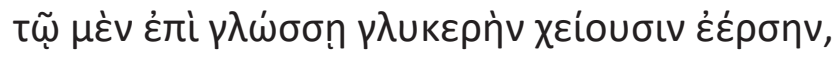

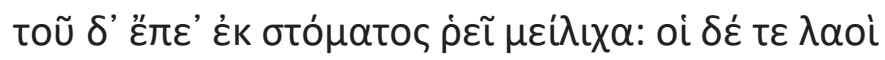

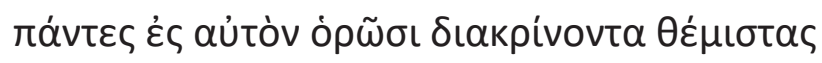

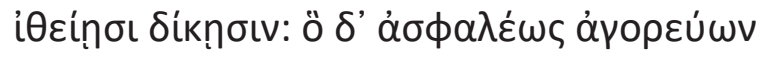

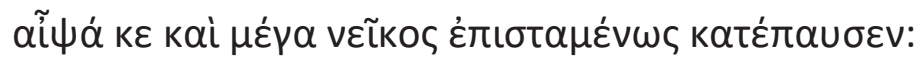

\footnotetext{
${ }^{4}$ Quanto à íntima relação entre as bem-faladas filhas de Zeus e os reis, ver Roth (1976).

${ }^{5}$ Quanto a essa função das Musas, vista a partir de uma dimensão política como produtora de efeito, pode-se consultar Colombani (2016).
} 


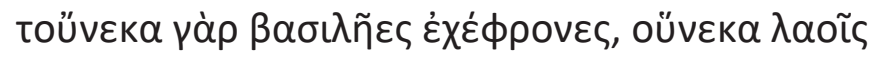

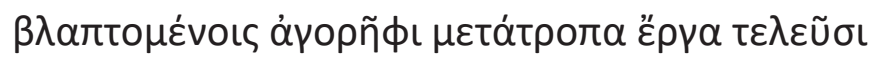

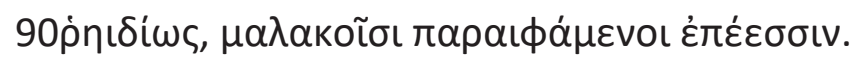

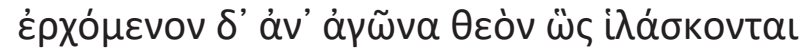

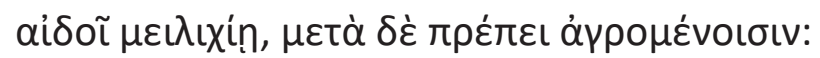

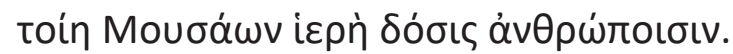

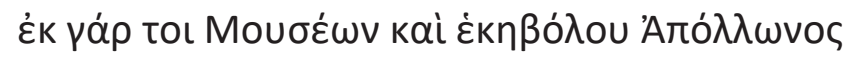

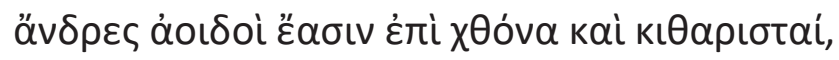

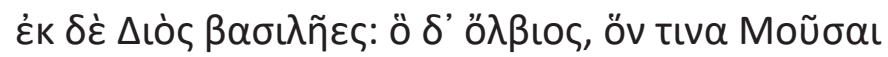

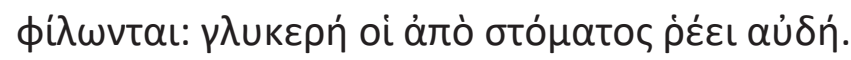

A quem honram as virgens do grande Zeus

e dentre reis sustentados por Zeus veem nascer,

elas the vertem sobre a lingua o doce orvalho

e palavras de mel fluem de sua boca. Todas

as gentes o olham decidir as sentenças

com reta justiça e ele firme falando na ágora

logo à grande discórdia cônscio põe fim,

pois os reis têm prudência quando às gentes

violadas na ágora perfazem as reparações

facilmente, a persuadir com brandas palavras.

Indo à assembleia, como a um Deus o propiciam

pelo doce honor e nas reuniões se distingue.

Tal das Musas o sagrado dom aos homens.

Teogonia, 81-936

A relação com o tópico em foco é nítida. O rei se erige como um protetor, um

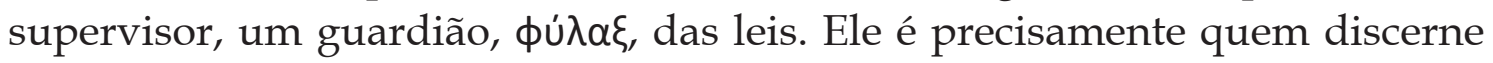

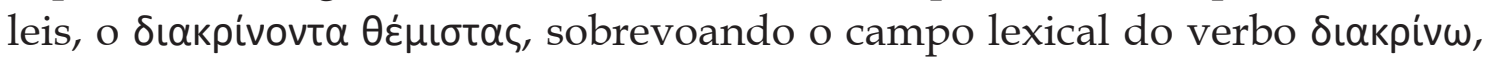
"separar", "distinguir", "decidir", "julgar". O objeto sobre o qual recai a ação

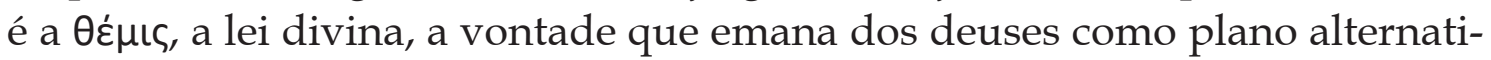
vo; é um decreto que provem da divindade, do além. Isso ocorre a partir de um poder e um saber que a sua condição de sujeito privilegiado lhe confere,

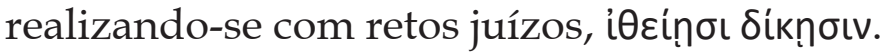

As marcas da luminosidade, tanto da função de soberania como do instru-

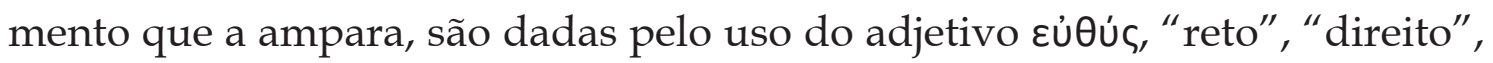

\footnotetext{
${ }^{6}$ Nota do tradutor: A tradução da Teogonia adotada neste trecho é a de Jaa Torrano, Teogonia. A origem dos deuses. $3^{a}$ edição. São Paulo: Ed. Iluminuras, 1995.
} 
"honrado", em clara oposição ao que será a ação dos dorophagoi - contramodelos da dimensão política.

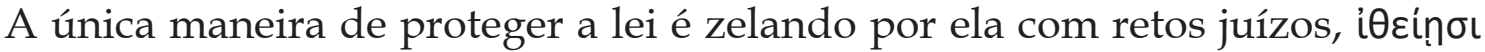

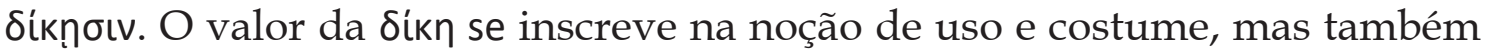
de juízo, sentença ou decreto, e isso abre a dualidade de planos que abrange o mito e a sua gramática. O rei discerne o que advém dos deuses, os quais habitam um plano que constitui um dos mundos ou raças abordados por L. Gernet (1981).

A tarefa de zelar pela lei não implica formas violentas de observar o legado divino. O rei administra um tipo de justiça que está em consonância com as marcas que as encantadoras filhas de Zeus lhe outorgaram; é uma figura diurna, de valência positiva, capaz de proporcionar à cidade os elementos que a beneficiam, em clara atividade protetora; por isso, de sua boca fluirão

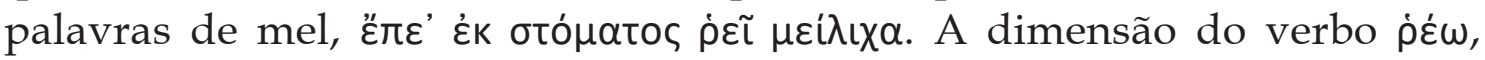
"emanar", "fluir", "brotar", reflete o modo como a palavra brota de um sujeito excepcional. Assim como ela emerge da boca de um poeta inspirado, de um mestre da alétheia.

O mito se vale dessas excepcionais figuras que constituem a província do mágico-religioso, topos intermediário entre os mortais e os Imortais. O rei é um intermediário da vontade dos deuses; suas palavras - عُлع - refletem essa dualidade de tópoi à qual nos referimos. $\mathrm{O}$ adjetivo $\mu \varepsilon \dot{\lambda} \lambda \iota x \circ$ s arremata o quadro de valência luminosa: doce, amável, suave. Tão suaves como as palavras de Nereu, o ancião do mar que constitui, sem dúvida, o vigário mítico da função de soberania.

Ora, há outro traço peculiar do rei que está associado a uma tarefa de pro-

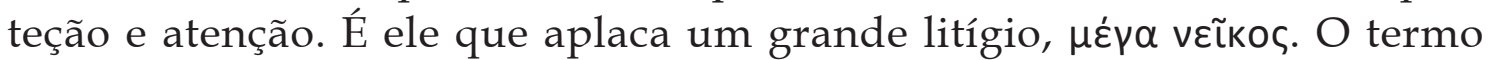
vعĩкo s alude à "disputa", "contenda", "querela", "objeto de discórdia", significados que nos situam na função de proteção da ordem e da concórdia que a comunidade exige para manter sua harmonia, isto é, sua saúde, se voltamos a propor a metáfora médica como uma maneira de compreender a comunidade à semelhança de um corpo, que obedece a certo ordenamento e coesão.

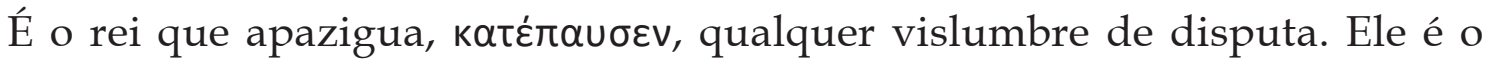

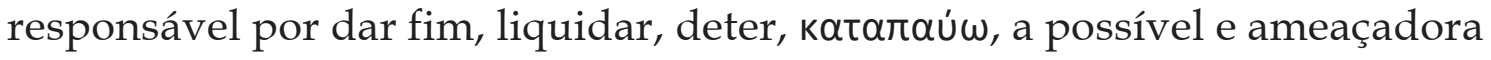
discórdia. A função de proteção e zelo com as leis exige sensatez, o que situa Hesíodo em uma intuição de absoluta atualidade que o converte em um clássico. Por seu intermédio, impõe-se o imperativo de uma sociedade mais

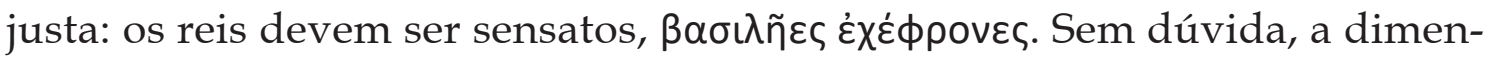

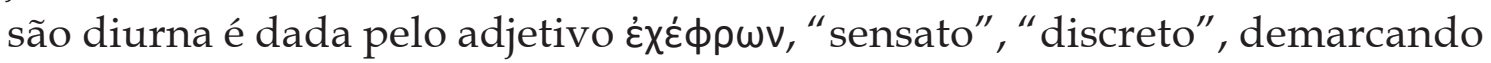


o horizonte da valência positiva que se une à doçura como marcas imprescindíveis da função de vigilância.

O rei tem uma dupla tarefa: zelar pela justiça como valor sobre o qual se assenta a saúde da aldeia e a coesão dos homens que a habitam, e zelar por aqueles que sofrem alguma forma de ofensa. No papel de defensor dos inju-

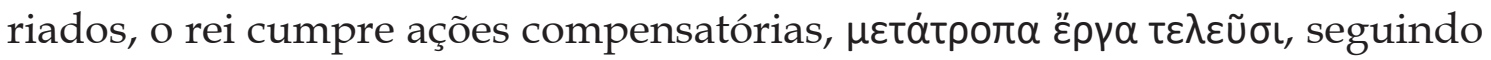

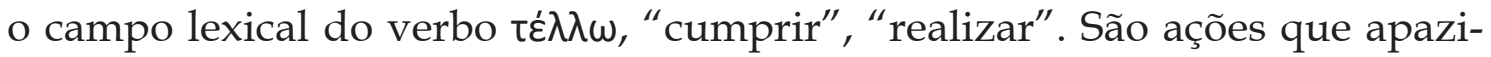

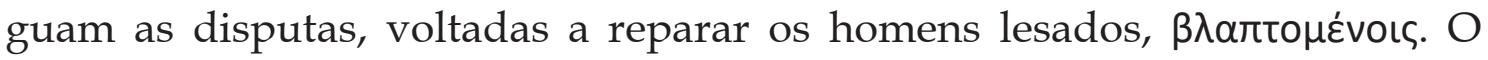
campo lexical do verbo $\beta \lambda \alpha ́ r \tau \omega$, de "prejudicar", "lesar", "ferir", está ligado ao coração daqueles que sofrem um dano, isto é, uma injustiça. A justiça ministrada pelo rei é terapêutica à medida que defende os homens dos danos causados pela injustiça como um mal a ser evitado.

Uma marca final da figura do rei é o respeito que ele impõe como um modelo de autoridade. A presença dos protetores e dos guardiões que zelam pelos valores positivos é reverenciada e venerada. Eles cumprem essa função de guarnecer o bem, que neutraliza a tudo o que atenta contra a ordem, e a todo eventual retorno a formas associadas ao kháos. Nesse sentido, a função de proteção é corretiva, debelando em sua ação qualquer forma de an-arkhia.

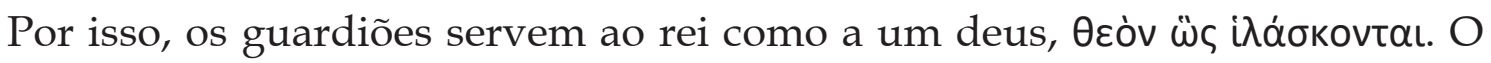

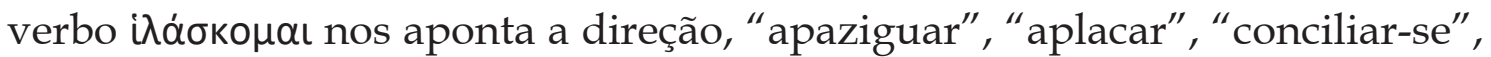
"propiciar". Estamos na presença de um gesto que homologa, de alguma forma, o estatuto ontológico do rei com o registro de um deus, estreitando assim a distância natural entre um plano e o outro ${ }^{7}$. Tal é a função social e religiosa do rei como mestre da alétheia (Detienne, 1986: 21-38); a ele se dirigem os guardiões com doce respeito, ai்oĩ $\mu \varepsilon \iota \lambda \iota x i n$.

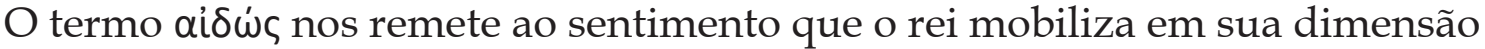
protetora, "pudor", "honra", "consideração", "respeito", incluindo reverência, enquanto que o adjetivo $\mu \varepsilon \iota \lambda i ́ x ı$ ç completa o quadro de valência diurna, "doce", "suave", "amável", que acode aos que o invocam. A imagem do mel continua presente no perfil identitário de quem faz do cuidado com o outro a sua função precípua.

\footnotetext{
7 Para os movimentos de aproximação e assimilação no universo mítico, ver Colombani (2005).
} 


\title{
Os daimones. Os trabalhos e os dias, e um novo horizonte de significação
}

\begin{abstract}
"Uma cultura da palavra legada com segurança à interpretação dos letrados, mas que - ninguém o duvidaria - está mais ligada à escuta e à memória do que à letra e à escritura".
\end{abstract}

Detienne, 1985: 33

Um novo segmento permite que nos situemos nessa cultura da palavra, nesse território do logos, no cenário de um relato que deve ser cuidadosamente escutado, assim como menciona a citação que abre estas nossas reflexões. O Mito das Idades é, sem dúvida, uma narração emblemática no contexto do que deve ser ouvido e recordado dentro da economia geral de uma palavra didática dirigida a um Tu, encarnado na figura de Perses, mas que se estende à humanidade como um todo ${ }^{8}$. A letra e a escritura cumprirão, a seu tempo, a sua tarefa. Por hora, o logos de Hesíodo se ergue como uma palavra didática a ser guardada no coração, que passa a notar, por intermédio do mito, a decadência cada vez maior dos homens após seu descenso a partir de uma raça áurea.

Propomo-nos, dessa forma, a revisitar Os Trabalhos e os Dias para salientar uma nova função de proteção e atenção que aparece no remate do surgimento da primeira raça apresentada no Mito das Idades. O Mito das Idades tematiza a injustiça e suas consequências para a evolução da Humanidade (Finley, 1966: $27)^{9}$. O problema é que tal decadência antropológica deve estar contida na tensão da hýbris-sophrosýne. Ainda que a sucessão, em si mesma, não implique uma decadência - tal como argumenta Fontenrose (1978: 8) - ela ainda assim pressupõe uma sucessão dialético-estrutural entre a desmesura e a medida. Porém, nossa posição frente ao relato e à perspectiva de Fontenrose ressalta a ideia de uma degradação ético-antropológica, entendida como uma forma de decadência dentro do cenário mais amplo de uma intenção didática ${ }^{10}$.

O Mito das Idades conduz Hesíodo por uma visão pessimista do futuro imediato, destinado a converter-se perigosamente no reino da hýbris e, como consequência, em uma ameaça real de caráter acósmico. O relato transita por diferentes etapas: a Idade do Ouro, a Idade da Prata, a Idade do Bronze, a Idade dos Heróis e a Idade de Ferro, em clara alusão à heterogeneidade dos metais e às suas qualidades.

\footnotetext{
8 Para o valor do mito como discurso e para uma análise exaustiva do mito das cinco raças, ver Crubellier (1996).

9 Mito de provável origem iraniana que, com o tempo, chegou à Grécia vindo do Oriente e é encontrado pela primeira vez em Hesíodo.

10 A respeito da dimensão didática da poesia hesiódica, ver Heath (1985).
} 
O mito como logos carregado de sentido é uma tentativa explicativa de dar conta da crescente degradação humana, que ocorre a partir do assenhoramento da hýbris sobre a prudência, em uma nítida relação política de dominação. Nesse processo, a desmesura passa a governar e a sophrosýne se vê submetida ao império da soberba, o qual determina uma série de punições e males, sempre presentes na hora de delinear o campo do sofrimento, da aridez e dos pesares, próprios do universo antropológico. Cada vez mais distantes da antiga convivência com os deuses, os homens se veem abrumados pelo pior dos tempos.

Por sua vez, a continuidade do mito das raças mostra como a gradual decadência acarreta a inviabilização de um kosmos humano sustentado pela ideia de justiça e concórdia. Sem dúvida, sua culminância representa a pior nudez antropológica, a absoluta intempérie dos homens mortais alcançada a partir da degradação. Aidós e Némesis deixarão os homens e se retirarão da terra rumo ao Olimpo, para viver junto aos imortais; essa sua retirada deixará aos humanos amargos sofrimentos e, por fim, não haverá remédio possível para tanta dor e tanto pesar (Os Trabalhos e os Dias, vv. 197-202). Ao concluir o relato do longo caminho da decadência e da injustiça, Hesíodo abre um panorama desolador de vínculos transidos pelo conflito ${ }^{11}$.

Até este ponto, temos uma visão global do desenvolvimento do mito e das consequências do esfacelamento da condição antropológica. Entretanto, nosso interesse atual está em situar o desaparecimento da primeira raça. Se nos remetemos ao início do relato, vemos que o vínculo entre a raça de ouro e a Justiça está testemunhado pelo destino atribuído aos homens áureos por Hesíodo, além da morte. Os homens dessa idade se convertem em daimones epictônicos, em gênios terrenais. Após caracterizar positivamente os homens da Idade de Ouro, o autor se refere ao seu ocaso - tal como o faz com cada uma das raças - pela ação de Zeus. Sepultados sob a terra e convertidos em daimones benignos, transfiguram-se em protetores dos homens.

Esse é o ponto que queremos levantar. Como afirma Rohde, "Os homens da raça de ouro já morreram e continuam vivendo fora de seus corpos, invisíveis, semelhantemente aos deuses e adornados, por isso mesmo, com um nome divinal privativo. Apresentam-se como os próprios deuses, em Homero, por múltiplas formas e figuras, percorrendo as cidades, vigiando os destemperos e as virtudes dos homens. Nisto, assemelham-se às almas dos defuntos" (1948: 58). Vamos ao texto:

${ }^{11}$ Concordamos com a análise de Neschke (1997:478) a respeito do Mito das Raças pela perspectiva da exortação e da poesia didática, mas, também, da consolidação de uma moral. 


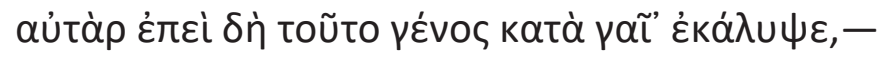

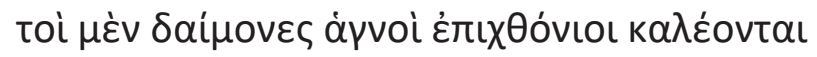

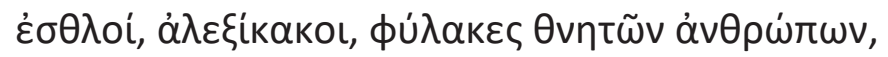

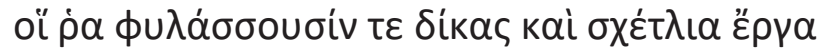

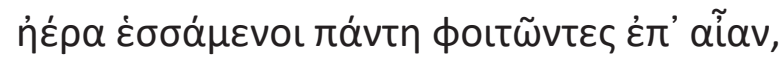

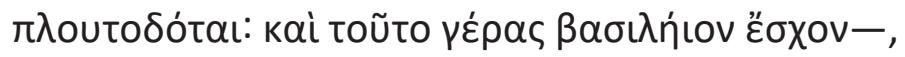

Mas desde que a terra encobriu essa raça,

eles são divindades pela vontade de Zeus grande,

nobres, terrestres, guardiões dos humanos perecíveis;

\{eles vigiam as sentenças e as cruéis ações,

vestidos de bruma, vagando por toda a terra,\}

distribuidores de riquezas: obtiveram esse privilégio de reis.

Os Trabalhos e os Dias, 121-126 12

O primeiro ponto que queremos destacar é a posição do Pai de todos os ho-

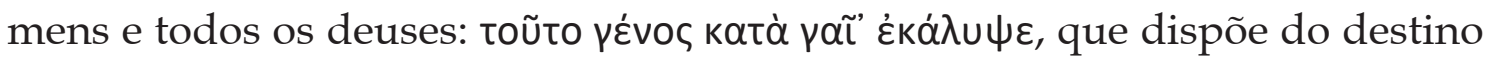
desses primeiros homens, tal como o fará também com as demais raças. $\mathrm{O}$

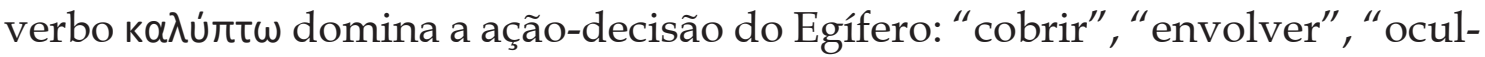

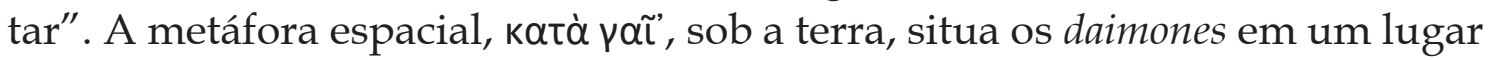
de invisibilidade. A soma de marcas identitárias estende sua inscrição em uma linhagem luminosa, de valência positiva, que complementará estruturalmente a função protetora e benfeitora.

Os espíritos são puros, àyvoi, inocentes, mas também sagrados, santos. O adjetivo reforça a familiaridade dos daimones com o divino, seu parentesco estrutural que os converte em aliados estratégicos da divindade para colaborar na

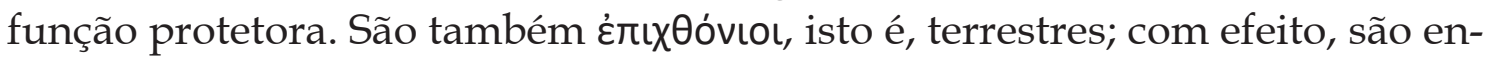
tidades que vivem na terra, terrenais, e essa superfície é a que os alberga para que cumpram a sua missão zeladora.

Sua próxima marca é definidora para o nosso atalho interpretativo. São salva-

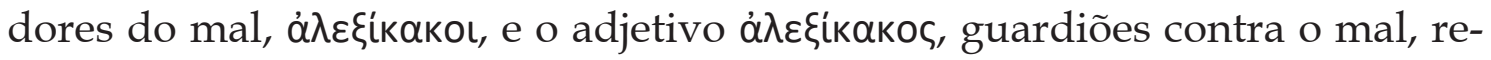
força a metáfora salvífica. Os daimones cumprem a função de ser protetores, defensores dos homens contra o mal. A imagem sobrevoa o campo lexical do verbo á $\lambda \dot{\varepsilon} \xi \omega$, "apartar", " proteger", " assistir", defender". Este é o campo simbólico de sua função protetora. Apartam o mal para defender os mortais que

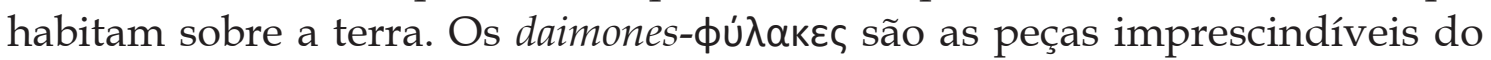

${ }^{12}$ Nota do tradutor: A tradução de Os Trabalhos e os Dias adotada nesta tradução é a de Alessandro Rolim de Moura. 22a edição. Curitiba: Ed. Segesta, 2012. 
dispositivo político de proteção que remove a maldade, lembrando assim a metáfora médica acima.

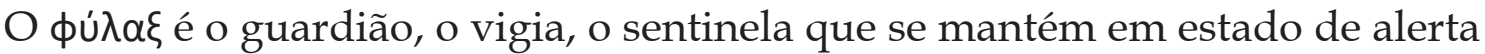
para proteger e defender a ordem. A chave é territorializar o mal, fixá-lo, encurralá-lo para que sua presença não destrua a tarefa ordenadora do Pai, garante da ordem e da justiça. Nesse sentido, dentro do contexto agonista que implica a tensão entre o bem e o mal, os daimones se convertem em aliados estratégicos de Zeus na tarefa de preservar o kósmos. Eles se tornam, por assim dizer, servidores da soberania.

Ora, pensemos: o que, exatamente, eles estão a vigiar? Aparece nesse ponto a tensão binária que Hesíodo costuma apresentar.

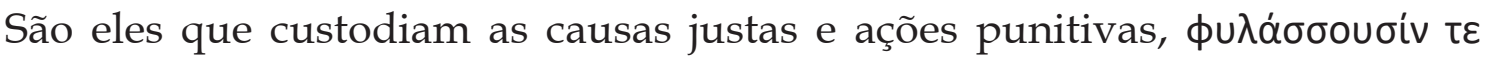

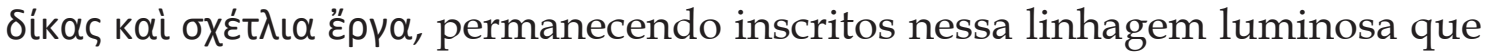
a arquitetura hesiódica reserva para as figuras positivas, que zelam pela ordem e a bondade. O substantivo రíkn não apenas alude à noção de justiça, mas também à ideia de causa, de costume - o modo de ser e operar. O que se está

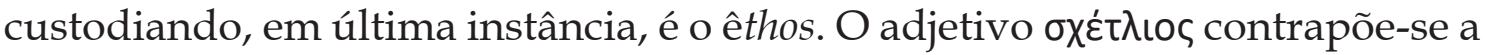
essa estrutura em espelho, abrindo um quadro de valência negativa: "insolente", "criminoso", “perverso", “abominável”, são algumas acepções do termo.

O modo como se movimentam essas deidades intermediárias, que em Hesíodo têm um signo positivo mas, em outras tradições, podem ter um signo oposto, é dado pela matiz do verbo фoıtw̃, ir e vir constantemente, andar de um lado para o outro; movimentam-se resguardando a totalidade do território, estabelecendo-se sobre a terra, '́л' aĩ $\alpha v$, sem deixar parte alguma descoberta. A imagem evoca um sentido de total vigilância, que alcança a todos os interstícios, vigiando-os e controlando-os.

Esse dispositivo joga com a invisibilidade como modo de funcionamento. Os

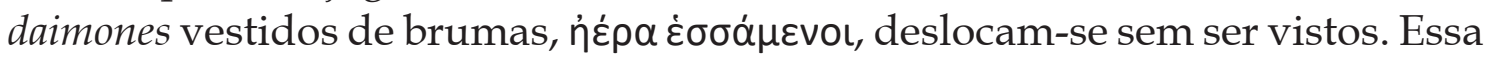
condição facilita a sua tarefa de controle, pois as bruma ou névoas, ảń $\rho$, geram essa circunstância privilegiada para o exercício da vigilância e ver sem ser visto. É um tipo de pan-óptico ${ }^{13}$ arcaico na missão de guarnecer as boas maneiras e ações que mantêm o kósmos em ordem, salvaguardando-o dos elementos associados ao mal. Sua matriz diurna se intensifica pela sua condição

${ }^{13}$ Em Vigiar e Punir, Foucault descreve a arquitetura do panóptico como um dispositivo emblemático das sociedades de controle. Trata-se de uma torre que possui um sistema de aberturas que inverte a relação entre ver e ser visto. Quem vigia pode observar a totalidade, sem que seja, por sua vez, visto. O controle se torna, assim, menos material e invisível. 
de doadores de riquezas, $\pi \lambda$ outoסótal, herdeiros diretos daqueles homens da raça áurea na qual a riqueza, $\pi \lambda$ oũtos, cumpria um papel preponderante. A sucessão da linhagem inscreve os daimones em um lugar de contato e semelhança com a divindade que é, habitualmente, doadora de riquezas.

Na mesma tradição, entende-se o final dos versos. Os protetores "obtiveram

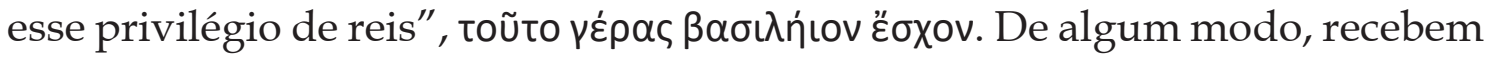
a mesma prerrogativa recebida pelos homens áureos: a familiaridade com o divino se expressa na forma de um privilégio. O termo үépas é decisivo para consumar a ligação entre os dois planos: é um presente de honra, uma distinção, privilégio, recompensa. Como em tantos outros aspectos que o mito reflete em seu relato ancestral, o gesto se inscreve na lógica do dom que materializa a escolha, por parte dos deuses, de certas entidades diletas a partir de sua irrevogável vontade.

Esse toque divino estabelece as linhas de continuidade genealógica e faz com que um herói, por exemplo, iguale-se a um deus. Sempre deve haver um elemento capaz de assegurar a continuidade entre um topos e outro.

\section{Conclusões}

"Histórias contadas desde sempre e incessantemente repetidas; todos as ouviram e as conservam na memória".

Detienne, 1985: 109

O projeto deste artigo foi o de pensar a dimensão do mito em Hesíodo como um produto do espírito humano a partir do que podemos considerar uma etho-mitho-poiética como um modo de instalação antropológica, e refletir sobre a capacidade do mito como operador de sentido. Hesíodo é, a nosso entender, um primeiro filósofo ou, pelo menos, um nítido expoente de um pensamento pré-filosófico que institui o complexo campo entre mito e filosofia, num terreno que gostamos de retratar pela imagem dos "caminhos emaranhados" - lembrando a expressão foucaultiana (Foucault, 1979). A partir desse lugar, buscamos recuperar uma atitude filosófica marcada por sua preocupação com a realidade histórica na qual está inserido, face-a-face com um futuro cheio de tenebrosidade, enquanto reconhece uma inquietação com a sabedoria de vida e os traços de um pensamento arcaico de marcado vigor e projeção ulterior (Rowe, 1983).

Também tratamos do que é, a nosso ver, a novidade hesiódica, ressaltando a arquitetura-andaime que dá sustentação e continuidade à sua obra, dentro da lógica da linhagem. A partir disso, destacamos duas figuras: a dos reis descendentes de Zeus e a dos daimones, que põem fim à idade áurea. Ambas 
estão inscritas em uma linhagem diurna, de valência positiva, e permitem-nos pensar na possibilidade de um otimismo frente ao estado das coisas.

A figura do rei nos mostrou um plexo de marcas identitárias recuperadas a partir da utilização da ferramenta filosófico-filológica que nos permitiu reconsiderar a função da soberania como a dimensão emblemática na qual confluem duas noções: a proteção e o cuidado.

Em um segundo momento, baseamo-nos no Mito das Idades para captar a visão pessimista do futuro imediato, a partir da ameaça de caráter acósmico que canaliza uma gradual degradação antropológica.

Nesse contexto, de um registro manifestamente patético, dentro do esquema agonista que inclui a tensão mesura-desmesura ao longo da obra, analisamos as marcas dos daimones convertidos em aliados políticos de Zeus na árdua tarefa de preservar o kósmos, a partir de sua dimensão de garantes da justiça. Uma vez mais, revisitamos os tópicos recortados e ambos - a proteção e o cuidado ou atenção - analisados sob a responsabilidade dos daimones, marcaram a recomendação do controle, a observância dos preceitos e o olhar atento como ferramentas imprescindíveis para a instituição e conservação da ordem.

\section{Referências bibliográficas}

COLOMBANI, María Cecilia. Hesíodo. Una introducción crítica. Buenos Aires: Santiago Arcos, 2005.

. Hesíodo. Discurso y Linaje. Una aproximación arqueológica. Mar del Plata: EUDEM, 2016.

CRUBELLIER, Michel. "Le mythe comme discours Le récit des cinq races humaines dans Les Travaux et Les Jours". Le métier du mythe. Lectures. París: Presse Universitaires du Septentrion, Vol. 16, 1996, pp. 435-463.

DETIENNE, Marcel. La invención de la mitología. Barcelona: Península, 1985.

DETIENNE, M. Los maestros de verdad en la Grecia Arcaica. Madrid: Taurus, 1986.

FINLEY, Moses I. El mundo de Odiseo. México: Fondo de Cultura Económica, 1966.

FONTENROSE, Joseph. "Work, justice, and Hesiod's five ages". Classical Philology, University of Chicago Press Vol. LXIX, N 1, 1974, pp. 1-16. 
FOUCAULT, Michel. "Nietzsche, la historia, la genealogía" Ídem Microfísica del poder. Barcelona: Ediciones La Piqueta, 1979.

. El orden del discurso. Barcelona: Tusquets, 1983.

. Vigilar y Castigar. Buenos Aires: Siglo XXI, 1989.

GERNET, Louis. Antropología de la Grecia Antigua. Madrid: Taurus, 1981.

GIGON, Olof. Problemas fundamentales de la filosofía griega. Buenos Aires: Compañía General Fabril Argentina, 1962.

Los orígenes de la filosofía griega. Buenos Aires: Gredos, 1985.

HEATH, Malcolm. "Hesiod's Didactic Poetry". The Classical Quarterly, New Series, Cambridge University Press, Vol. 35, n² 2, 1985, pp. 245-263.

HESIOD. Theogony. Works and Days. Testimonia. Most, G. W. (editor and translator). London: Loeb Classical Library, Harvard University Press, 2006.

HESÍODO. Obras y fragmentos. Madrid: Gredos, 2000.

LIÑARES, Lucía. Hesíodo Teogonía, Trabajos y Días. Edición bilingüe, Buenos Aires: Losada, 2005.

NESCHKE, Ada. "Dikè. La philosophie poétique du droit dans le "mythe des races" d'Hésiode". Le métier du mythe. Lectures d'Hésiode, sous Paris: Presse Universitaires du Septentrion, Vol. 16, 1993, pp. 465-478.

RODRÍGUEZ ADRADOS, Francisco. “La composición de los poemas hesiódicos". EMÉRITA, Revista de Lingüística y Filología Clásica (EM), LXIX 2, 2001, pp. 197-223.

ROHDE, Erwin. Psique. La idea del alma y la inmortalidad entre los griegos. México: Fondo de Cultura Económica, 1948.

ROTH, Catharine P. "Kings and Muses in Hesiod's 'Theogony'”. Transactions of the American Philological Association (1974), The John Hopkins University Press, Vol. 106, 1976, pp. 331-338.

ROWE, Christopher J. "'Archaic Thought' in Hesiod". The Journal of Hellenic Studies, The Society for the Promotion of Hellenic Studies, Vol. 103, 1983, pp. 124-135.

VIANELLO DE CÓRDOVA, Paola. Hesíodo Teogonía. México: Universidad Nacional Autónoma de México, 1978. 